\title{
Características bromatológicas e fermentativas de silagens de capim elefante contendo casca de soja peletizada
}

\section{Bromatological and fermental characteristics of elegant capim silexes containing peletized soybean shell}

\author{
Caroline Pimentel Maia ${ }^{1}$, Andréa Krystina Vinente Guimarães ${ }^{2 *}$, Andressa Santana Costa ${ }^{1}$, \\ Daniel Parente Barbosa ${ }^{3}$, José Jeosafá Vieira de Sousa Júnior ${ }^{1}$, Silvia Katrine Rabelo da Silva ${ }^{1}$
}

\section{RESUMO}

Este experimento foi conduzido a fim de avaliar as características nutritivas de silagens de capim-elefante cv. Cameroon com $0 ; 5 ; 10 ; 15 ; 20$ e $25 \%$ de adição da casca de soja peletizada. O delineamento experimental foi inteiramente casualizado com quatro repetições. Determinaram-se os teores de nutrientes, população microbiana e estabilidade aeróbia. Os teores de matéria seca, nitrogênio amoniacal e pH foram elevados em 3,02; 0,43 e 0,09\%, respectivamente, a cada $1 \%$ da adição da casca de soja. A inclusão da casca de soja reduziu a população de leveduras. As silagens com inclusão de 5\% tiveram sua estabilidade quebrada após $24 \mathrm{~h}$ de exposição ao ar enquanto os níveis de maior inclusão (20 e $25 \%$ ) levaram 48 horas para ultrapassar $2^{\circ} \mathrm{C}$ acima da temperatura ambiente. A inserção da casca de soja na silagem de capim elefante melhora o perfil fermentativo, composição química e reduz a população microbiana em inclusões acima de $15 \%$.

Palavras-chave: Aditivo; Estabilidade aeróbia; Fermentação; Valor nutritivo;

\begin{abstract}
This experiment was carried out in order to evaluate the nutritive characteristics of elephant grass silages cv. Cameroon with $0 ; 5 ; 10 ; 15 ; 20$ and 25\% addition of pelleted soy hulls. The experimental design was completely randomized with four replications. Nutrient contents, microbial population and aerobic stability were determined. The dry matter, ammonia nitrogen and $\mathrm{pH}$ contents were increased in 3.02; 0.43 and $0.09 \%$, respectively, for each $1 \%$ of the addition of soybean hulls. The inclusion of soybean husk reduced the yeast population. The silages with 5\% inclusion had their stability broken after 24 hours of exposure to air while the levels of greater inclusion ( 20 and $25 \%$ ) took 48 hours to exceed $2^{\circ} \mathrm{C}$ above room temperature. Inserting soy husks into elephant grass silage improves the fermentation profile, chemical composition and reduces the microbial population at inclusions above $15 \%$.
\end{abstract}

Keywords: Additive; Aerobic stability; Fermentation; Nutritive value.

\footnotetext{
${ }^{1}$ Universidade Federal do Oeste do Pará.

${ }^{2}$ Universidade Federal do Oeste do Pará. *E-mail: andreavinente @ gmail.com

3 Universidade Federal do Amazonas.
} 


\section{INTRODUÇÃO}

A estacionalidade climática no Brasil afeta diretamente a produção de forragem e consequentemente as condições nutricionais dos rebanhos, uma vez que no período seco há menor crescimento e baixo valor nutritivo das gramíneas, no entanto, uma das alternativas para suprir essa carência é a conservação do excedente de forragem na forma de silagem para suprimento das carências nutricionais durante o verão agrostológico (RIBEIRO et al., 2009; BONFÁ et al., 2015).

O capim cameroon (Pennisetum purpureum Schum.), muito utilizado pelos pecuaristas, possui alto potencial forrageiro, o que faz dessa gramínea uma das mais utilizadas e difundidas nas regiões tropicais, com grande importância para a produção animal, contudo, suas características morfológicas, composição química e teor de matéria seca podem ser alterados em função das condições climáticas (OLIVEIRA et al., 2011).

Quando atinge estágio adequado para ser ensilada, essa gramínea apresenta alta umidade, baixos teores de carboidratos solúveis e alto poder tampão, limitando seu uso como silagem, pois esses fatores, quando em conjunto, prejudicam o processo fermentativo, dando margem para desenvolvimento de microrganismos deterioradores, como as enterobactérias, produtoras de nitrogênio amoniacal, ácido acético e ácido butírico (SILVA et al., 2011)

Para melhorar o valor nutritivo têm-se adicionado à silagem de capim elefante alguns aditivos com o objetivo de melhorar a fermentação, aumentar o teor de matéria seca, garantir o mínimo de perdas de matéria seca, limitando assim a atividade proteolítica e clostrídica, para isso, esses aditivos devem ser de materiais secos com capacidade de retenção de água, alto teor de carboidratos solúveis, de fácil manipulação, disponibilidade e baixo custo de aquisição (ANDRADE et al., 2012).

Com isso, a casca de soja, subproduto do beneficiamento do grão de soja, podendo ser usada como volumoso e concentrado, surge como uma das alternativas para elevar a matéria seca e o valor nutricional da silagem de capim elefante, sobre os aspectos nutricionais, apresenta elevada digestibilidade de seus nutrientes, $90 \%$ de matéria seca, $81 \%$ de fibra em detergente neutro, $62 \%$ de fibra em detergente ácido e proteína bruta estimada em 11\% (CASALI et al., 2009; MATEUS et al., 2018). 
O objetivo deste experimento foi avaliar a silagem de capim elefante cv. cameroon com seis níveis de adição $(0,5,10,15,20$ e 25\%) da casca de soja peletizada considerando a composição químico-bromatológica, a população microbiana e a estabilidade aeróbia.

\section{MATERIAL E MÉTODOS}

O ensaio foi efetivado nas dependências da Universidade Federal do Oeste do Pará - UFOPA, localizada no município de Santarém, PA (02²6’35” S e 5442’30” W). O capim elefante foi colhido manualmente na fazenda experimental da fazenda experimental da UFOPA, processado em picadeira de forragem convencional, com tamanho de partículas de aproximadamente três $\mathrm{cm}$.

A forragem colhida foi submetida a seis níveis $(0 ; 5 ; 10 ; 15 ; 20$ e $25 \%$ com base na matéria natural) de adição da casca de soja na ensilagem de capim-elefante. A casca de soja peletizada misturada à massa, foi proveniente da compra em lojas agropecuárias na cidade de Santarém, PA. A composição químico-bromatológica do aditivo utilizado e dos tratamentos está descrito na tabela 1 .

Tabela 1. Composição bromatológica da casca de soja peletizada e dos tratamentos antes da ensilagem.

\begin{tabular}{lccccccc}
\hline \multirow{2}{*}{ Variável } & \multirow{2}{*}{ Casca } & \multicolumn{7}{c}{ Nível de casca de soja peletizada (\%) } \\
\cline { 3 - 8 } & & 0 & 5 & 10 & 15 & 20 & 25 \\
\hline Matéria Seca (\%) & 83,7 & 15,9 & 17,2 & 20,5 & 23,8 & 26,5 & 30,6 \\
Matéria Mineral (\%) & 3,7 & 9,3 & 7,8 & 7,1 & 6,8 & 6,4 & 6,0 \\
Matéria Orgânica (\%) & 96,3 & 90,7 & 92,2 & 92,9 & 93,2 & 93,6 & 94,0 \\
Fibra em Detergente Ácido (\%) & 52,2 & 48,7 & 50,9 & 48,0 & 51,1 & 50,0 & 51,6 \\
Fibra em Detergente Neutro (\%) & 65,1 & 66,3 & 67,2 & 63,1 & 64,4 & 61,2 & 66,0 \\
Proteína Bruta (\%) & 9,8 & 6,8 & 8,7 & 7,1 & 8,9 & 9,5 & 8,9 \\
NIDA (\%) & 0,2 & 0,5 & 0,5 & 0,4 & 0,5 & 0,4 & 0,5 \\
PIDA (\%) & 1,1 & 2,8 & 3,4 & 2,2 & 2,8 & 2,7 & 2,8 \\
Extrato etéreo (\%) & 10,0 & 11,1 & 10,1 & 10,2 & 9,6 & 11,0 & 9,5 \\
Carboidratos Totais (\%) & 76,5 & 73,0 & 73,4 & 75,7 & 74,9 & 73,2 & 75,7 \\
Carboidratos Não Fibrosos (\%) & 11,5 & 6,7 & 6,3 & 12,7 & 10,6 & 12,0 & 9,6 \\
\hline
\end{tabular}

NIDA- Compostos nitrogenados insolúveis em detergente ácido; PIDA- proteína insolúvel em detergente ácido. 
O delineamento experimental utilizado na avaliação dos níveis de inclusão do aditivo na silagem de capim elefante foi inteiramente casualizado, com quatro repetições. Como silos experimentais, foram utilizados 24 silos de PVC com $10 \mathrm{~cm}$ de diâmetro e $35 \mathrm{~cm}$ de comprimento, com capacidade para 1,650 kg de foragem. A compactação foi realizada manualmente com auxílio de soquete de madeira, atingindo densidade de $600 \mathrm{~kg} / \mathrm{m}^{3}$. Completado o enchimento, os silos receberam tampa de plástico apropriada à vedação e adaptadas com válvula do tipo Bunsen para escape dos gases e acondicionados em temperatura ambiente.

A avaliação das silagens foi realizada 40 dias após o fechamento. No dia de abertura, foram descartados aproximadamente $10 \mathrm{~cm}$ dos conteúdos superiores de cada silo, para maior confiabilidade das análises. Foi aferida a temperatura no interior do silo com auxílio de termômetro digital inserido na massa ensilada, em profundidade de 10 $\mathrm{cm}$.

Para a determinação da composição bromatológica foi pesado $500 \mathrm{~g}$ de cada repetição, acondicionadas em sacos de papel, levados em estufa de ventilação forçada, mantida na temperatura de 55 a $60^{\circ} \mathrm{C}$, por 72 horas. As amostras pré-secas foram moídas em moinho de faca tipo Willey, com peneira de malha de $1 \mathrm{~mm}$. Nestas amostras foram determinadas: matéria seca (MS), matéria mineral (MM), matéria orgânica $(\mathrm{MO})$, proteína bruta $(\mathrm{PB})$, extrato etéreo $(\mathrm{EE})$, de acordo com técnicas descritas por AOAC (1990). O EE foi determinado com adaptação, consistindo na pesagem de $2 \mathrm{~g}$ de amostra em cartuchos de papel filtro, posteriormente colocados nos tubos com $170 \mathrm{ml}$ de éter etílico. A extração foi realizada com a amostra mergulhada no éter por 4 horas à $50^{\circ} \mathrm{C}$. Logo após o processo os cartuchos foram retirados, levados em estufa a $105^{\circ} \mathrm{C}$, por 12 horas e pesados para obtenção do EE.

As fibras em detergente neutro (FDN) e em detergente ácido (FDA) foram determinadas conforme a metodologia de Van Soest; Robertson; Lewis (1991). A digestão para obtenção do FDN e FDA foi realizada em aparelho de digestão de fibra, similar ao Ankon. Os teores de compostos nitrogenados insolúveis em detergente ácido (NIDA) foram estimados nos resíduos obtidos após extração das amostras no detergente ácido, respectivamente (VAN SOEST et al., 1991), por intermédio do procedimento de micro Kjeldahl (AOAC, 1990). A correção da FDN para cinzas e da FDA para os 
compostos nitrogenados e a estimação dos conteúdos de proteína insolúvel no detergente ácido (PIDA) foram feitas conforme Licitra; Hernandes; Van Soest (1996).

Os nutrientes digestíveis totais (NDT) e digestibilidade da matéria seca (DMS), foram estimados segundo Rodrigues (2010), pelas equações: NDT $=87,84-(0,7 \mathrm{x}$ FDA), DMS = 88,9 - (0,779 x FDA), carboidratos não fibrosos (CNF) obtidos por intermédio da equação: $100-(\% \mathrm{FDN}+\% \mathrm{~PB}+\% \mathrm{EE}+\% \mathrm{MM})$ de acordo com Weiss (1999) e carboidratos totais (CT) pela equação: $100-(\% \mathrm{~PB}+\% \mathrm{EE}+\% \mathrm{MM})$ segundo Sniffen et al. (1992).

A análise de nitrogênio amoniacal foi realizada em amostras previamente congeladas, onde foram retiradas $25 \mathrm{~g}$ de amostras de silagens. As analises foram determinadas seguindo a metodologia de Bolsen et al. (1992) e pH de acordo com Silva; Queiroz (2002).

A determinação da população microbiana foi feita utilizando uma diluição 10-1, com $10 \mathrm{~g}$ de silagem diluída em $90 \mathrm{ml}$ de solução tampão fosfato estéril, seguida de diluições em série, variando de 10-1 até 10-4 e, após, efetuaram-se os plaqueamentos em meios de cultura seletivos para os grupos de mofos, leveduras, E. coli e coliformes totais, pipetando $1 \mathrm{ml}$ dessa solução em cada placa de Petri. O grupo de mofos e leveduras foi enumerado utilizando-se o meio Ágar Sabouraud Dextrose, e o grupo de E. coli e coliformes totais em meio Cromcult, conforme os critérios citados por Silva et al. (2007). Os dados obtidos das contagens microbianas foram expressos em unidades formadoras de colônias (UFC/ml) de silagem e analisados conforme os procedimentos adotados por González; Rodriguez (2003).

A estabilidade aeróbia foi avaliada com uma amostra composta para cada tratamento $(0,5,10,15,20,25 \%$ de inclusão da casca de soja peletizada) com $2 \mathrm{~kg}$ de silagem não compactado e acondicionado em baldes de polipropileno com capacidade para $15 \mathrm{~kg}$ e armazenados em uma sala fechada com temperatura média de $27^{\circ} \mathrm{C}$. Foram avaliados 15 tempos de avaliação $(0,24,36,48,60,72,84,96,108,120,132,144,156$, 168 e 180 horas após a abertura dos silos) onde foram tomados os valores de temperatura ambiente, temperatura da silagem e valores de $\mathrm{pH}$ para cada horário avaliado, segundo a metodologia descrita por Silva; Queiroz (2002).

As médias da composição químico-bromatológica foram submetidas à análise estatística, utilizando o teste de Scott-Knott, considerando o valor de $\mathrm{P}<0,05$ como nível de significância. Posteriormente as médias foram submetidas à análise de regressão em 
função dos níveis de aditivo utilizados. A escolha do modelo foi feita com base no coeficiente de determinação, na significância da regressão e dos seus coeficientes em nível de 5\% de probabilidade. As médias da estabilidade aeróbia foram submetidas ao teste de agrupamento de médias de Scott-Knott, considerando o valor de $\mathrm{P}<0,05$. O programa utilizado para realização das análises foi o SISVAR 5.6 ® (FERREIRA, 2011).

\section{RESULTADOS E DISCUSSÃO}

A adição da casca de soja peletizada na ensilagem do capim elefante não influenciaram $(\mathrm{P}>0,05)$ os teores de compostos nitrogenados insolúveis em detergente ácido, proteína insolúvel em detergente ácido, nem nos valores de carboidratos totais (Tabela 2).

Tabela 2. Composição químico-bromatológica da silagem de capim elefante com níveis de inclusão de casca de soja peletizada

\begin{tabular}{|c|c|c|c|c|c|c|c|c|c|}
\hline \multirow{2}{*}{ Variável } & \multicolumn{6}{|c|}{ Nível de casca de soja peletizada (\%) } & \multirow{2}{*}{ P } & \multirow{2}{*}{ Equação de regressão } & \multirow{2}{*}{$\mathrm{R}^{2}$} \\
\hline & 0 & 5 & 10 & 15 & 20 & 25 & & & \\
\hline MS (\%) & $16,2 \mathrm{f}$ & $18,9 \mathrm{e}$ & $21,3 \mathrm{~d}$ & $25,0 \mathrm{c}$ & $28,1 \mathrm{~b}$ & $31,2 \mathrm{a}$ & 0,000 & $\hat{y}=3,02 x+12,86^{*}$ & $99 \%$ \\
\hline MM (\%) & $8,0 \mathrm{a}$ & $8,0 \mathrm{a}$ & $7,7 \mathrm{a}$ & $6,5 b$ & $6,6 b$ & $7,0 \mathrm{~b}$ & 0,007 & & \\
\hline $\mathrm{MO}(\%)$ & $92,0 \mathrm{~b}$ & $92,0 \mathrm{~b}$ & $92,3 b$ & $93,5 \mathrm{a}$ & $93,4 \mathrm{a}$ & $93,0 \mathrm{a}$ & 0,007 & & \\
\hline FDA (\%MS) & $44,0 \mathrm{~b}$ & $44,3 \mathrm{~b}$ & $45,3 b$ & $43,6 b$ & $45,9 b$ & $48,8 \mathrm{a}$ & 0,004 & & \\
\hline FDN (\%MS) & $60,8 \mathrm{a}$ & $57,6 \mathrm{~b}$ & $58 \mathrm{~b}$ & $59,1 \mathrm{a}$ & $55,8 \mathrm{~b}$ & $57,2 b$ & 0,008 & & \\
\hline NDT (\%MS) & $57,0 \mathrm{a}$ & $56,8 \mathrm{a}$ & $56,1 \mathrm{a}$ & $57,3 \mathrm{a}$ & $55,7 \mathrm{a}$ & $53,7 \mathrm{~b}$ & 0,004 & & \\
\hline DMS (\%MS) & $54,6 \mathrm{a}$ & $54,4 \mathrm{a}$ & $53,6 \mathrm{a}$ & $54,9 \mathrm{a}$ & $53,2 \mathrm{a}$ & $50,9 b$ & 0,004 & & \\
\hline $\mathrm{EE}(\% \mathrm{MS})$ & $10,4 \mathrm{a}$ & $10,3 a$ & $9,5 \mathrm{~b}$ & $9,1 \mathrm{~b}$ & $9,6 \mathrm{~b}$ & $9,4 \mathrm{~b}$ & 0,000 & & \\
\hline $\begin{array}{l}\mathrm{N}-\mathrm{NH}_{3} \\
(\% \mathrm{NT})\end{array}$ & $2,9 b$ & $2,9 b$ & $3,1 b$ & $3,7 b$ & $5,0 \mathrm{a}$ & $4,5 \mathrm{a}$ & 0,000 & $\hat{y}=0,43 x+2,16^{*}$ & $82 \%$ \\
\hline PB (\%MS) & $7,2 \mathrm{~b}$ & $8,6 \mathrm{a}$ & $8,9 \mathrm{a}$ & $9,3 \mathrm{a}$ & $9,0 \mathrm{a}$ & $9,8 \mathrm{a}$ & 0,000 & & \\
\hline $\begin{array}{l}\text { NIDA } \\
(\% \mathrm{MS})\end{array}$ & $0,8 \mathrm{a}$ & $0,7 \mathrm{a}$ & $0,7 \mathrm{a}$ & $0,7 \mathrm{a}$ & $0,7 \mathrm{a}$ & $0,6 \mathrm{a}$ & 0,356 & $\hat{y}=-0,03 x+0,80 *$ & $87 \%$ \\
\hline $\begin{array}{l}\text { PIDA } \\
(\% \mathrm{MS})\end{array}$ & $4,9 \mathrm{a}$ & $4,5 \mathrm{a}$ & $4,7 \mathrm{a}$ & $4,4 \mathrm{a}$ & $4,2 \mathrm{a}$ & $4,0 \mathrm{a}$ & 0,356 & $\hat{y}=-0,17 x+5,02^{*}$ & $87 \%$ \\
\hline CT (\%MS) & $74,4 \mathrm{a}$ & $73,0 \mathrm{a}$ & $74,0 \mathrm{a}$ & $75,0 \mathrm{a}$ & $74,9 a$ & $73,8 \mathrm{a}$ & 0,055 & $\begin{array}{c}\hat{y}=-0,19 x^{3}+1,94 x^{2}-5,57 x \\
+78,14^{*}\end{array}$ & $91 \%$ \\
\hline CNF (\%MS) & $13,6 \mathrm{~b}$ & $15,4 \mathrm{~b}$ & $16,0 \mathrm{~b}$ & $16,0 \mathrm{~b}$ & $19,1 \mathrm{a}$ & $16,6 \mathrm{~b}$ & 0,017 & & \\
\hline TEM $\left({ }^{\circ} \mathrm{C}\right)$ & $25,2 \mathrm{a}$ & $24,7 \mathrm{a}$ & $24,2 b$ & $24,7 \mathrm{a}$ & $24,2 b$ & $24,2 b$ & 0,013 & & \\
\hline
\end{tabular}


*Significativo a $5 \%$ de probabilidade.

Médias seguidas de mesma letra na linha não diferem entre si pelo teste de Scott-Knott a $5 \%$ de significância.

MS - matéria seca, MM - matéria mineral, MO - matéria orgânica, FDA - fibra em detergente ácido, FDN - fibra em detergente neutro, NDT - nutrientes digestíveis totais, DMS digestibilidade da matéria seca, $\mathrm{EE}$ - extrato etéreo, N-NH3 - nitrogênio amoniacal, $\mathrm{PB}$ proteína bruta, NIDA - compostos nitrogenados insolúveis no detergente ácido, PIDA - proteína insolúvel no detergente ácido, CT - carboidratos totais, CNF - carboidratos não fibrosos, TEM - temperatura das silagens.

Fonte: Maia et al., (2021, p.07)

Houve aumento significativo no teor de matéria seca em função dos níveis de aditivo utilizado $(\mathrm{P}<0,05)$, com menores valores, $16,2 \%$, na silagem exclusiva de capim elefante e 31,2\% na MS do maior nível, 25\% de inclusão, com acréscimo linear de $3,02 \%$ para cada unidade de casca de soja adicionado a silagem, conforme equação de regressão. De modo semelhante, Monteiro et al. (2011) adicionaram casca de soja (10\% com base na matéria natural) na ensilagem de capim elefante contendo $17,87 \%$ de MS e verificaram aumento no teor de matéria seca, encontrando valores de $31,65 \%$ nesse nível de inclusão.

As matérias mineral e orgânica foram influenciadas pelos níveis de inclusão ( $\mathrm{P}<0,05)$, com maiores teores de $\mathrm{MM}$, de 8,8 e 7,7\%, nas silagens com inclusão de 0,5 e $10 \%$, respectivamente. Foi observado aumento significativo de MO nas silagens que continham 15 a $25 \%$ de inclusão do aditivo. Esses resultados corroboram com os encontrados por Maia et al. (2015) que ao avaliarem o subproduto da acerola na silagem de capim elefante observaram aumento de 1,18 pontos percentuais no teor de matéria orgânica em seu nível mais alto de inclusão (20\%).

Para os teores de fibra, a casca de soja, devido à sua espessa parede celular, proporcionou valores superiores de FDA nas silagens com aditivo, com teores de 48,8\% no nível mais alto de inclusão (25\%). No entanto, os teores de FDN reduziram a medida que se elevou a inclusão de casca de soja na silagem, com maiores valores (60,8 e $59,1 \%$ ) nos níveis de 0 e $15 \%$, respectivamente. Os resultados desta pesquisa corroboram os apresentados por Rêgo et al. (2010), que encontraram na silagem exclusiva de capim elefante valores superiores de FDA e FDN, com teores, 
respectivamente, de 48,89\% e 74,25\%. Esses resultados podem ser explicados pelo fato da casca de soja apresentar maior teor de FDA e menor de FDN quando comparado aos teores do capim elefante (Tabela 1).

Os teores de NDT e DMS apresentaram diferenças significavas entre os tratamentos $(\mathrm{P}=0,004)$, com menores valores na silagem adicionada de $25 \%$ de casca de soja, 53,7 e 50,9 de nutrientes digestíveis totais e digestibilidade da matéria seca.

Para Stella et al. (2016) uma silagem com adequado teor energético, deve apresentar entre 64 a 70\% de NDT e, portanto, as silagens de capim elefante exclusiva e com acréscimo da casca de soja nos níveis estudados não seriam recomendadas como fonte única de volumoso na dieta. Com relação a digestibilidade da matéria seca, Bonfá et al. (2015) sugere que menores valores de digestibilidade estão associados ao tempo de retenção da forragem no rúmen, promovendo limitações de consumo de ordem física.

O teor de extrato etéreo sofreu influência dos níveis de adição da casca de soja $(\mathrm{P}<0,05)$, apresentando teores mais elevados, 10,4 e 10,3\%, na silagem exclusiva de capim elefante e no nível de 5\%, respectivamente, não havendo diferença estatística entre os demais tratamentos. Tal fato pode ser explicado pelo baixo teor desse nutriente na casca de soja quando comparado ao teor encontrado no capim elefante (Tabela 1). Os resultados dessa pesquisa diferem dos encontrados por Andrade et al. (2010), que observaram aumento nos teores de EE quando utilizou o farelo de cacau como aditivo na ensilagem do capim-elefante.

Foi observado aumento linear de nitrogênio amoniacal, com incremento de 0,43\% para cada unidade da adição da casca de soja na silagem de capim elefante. Os níveis de 20 e $25 \%$ de casca de soja proporcionaram os maiores aumentos do teor de nitrogênio amoniacal das silagens de capim elefante (5\% e 4,5, respectivamente), ainda assim, todas as silagens apresentaram teores adequados, uma vez que Ribeiro et al. (2009) classifica silagens com teor de N-NH3 inferior a 10\% do N Total como desejáveis, enquanto teores de N-NH3 entre 10 e 15\% do N Total, são consideradas como aceitáveis.

A silagem exclusiva de capim elefante apresentou em média 7,2\% de PB, diferindo daquelas com casca de soja peletizada, sendo o máximo nível de inclusão responsável pelo maior teor de proteína bruta encontrado nas massas avaliadas $(9,8 \%)$, esses valores foram superiores aos descritos por Guerra et al. (2016), que encontraram em silagens de capim elefante controle $(4,71 \%$ de PB) e aumento de $0,10 \%$ na proteína 
bruta em cada unidade de casca de maracujá desidratado adicionado na silagem. Da mesma forma, Ferreira et al. (2009) observaram baixos teores de PB $(5,5 \%)$ nas silagens de capim-elefante.

Os teores de NIDA e PIDA não apresentaram diferença entre os tratamentos $(\mathrm{P}>0,05)$, no entanto houve efeito linear decrescente, sendo que a cada $1 \%$ da casca de soja inclusa havia redução de $0,03 \%$ no teor de compostos nitrogenados insolúveis em detergente ácido e decréscimo de $0,17 \%$ na proteína insolúvel em detergente ácido. Com relação a essas variáveis, Oliveira et al. (2012) cita que correspondem à proteína indisponível, associadas a compostos resistentes a degradação por microrganismos e à ação de enzimas, por isso, essas frações são consideradas inaproveitáveis pelos ruminantes.

Os teores de carboidratos totais não apresentaram diferença significativa $(\mathrm{P}>0,05)$ entre os níveis, constatando que, o maior percentual desse nutriente na casca de soja não aumentou os percentuais de CT das silagens, entretanto, observou-se efeito cúbico da adição da casca de soja sobre as silagens, com teor máximo estimado em $75,09 \%$ para o nível de $4,75 \%$ e teor mínimo de $73,24 \%$ para o nível de $2,06 \%$. Maia et al. (2015) observaram valores de $85,35 \%$ de CT em silagens exclusivas de capim elefante, esses valores foram inferiores aos encontrados nesta pesquisa, na qual foram obtidos teores de 74,4\% nas silagens apenas de capim elefante.

Os teores de CNF nas silagens de capim elefante com casca de soja peletizada aumentaram linearmente. Segundo Mateus et al. (2018) a fração de carboidratos não fibrosos pode ser dividida em carboidratos simples e carboidratos complexos, sendo absorvidos rapidamente pelo trato gastrointestinal, e usados como fonte de energia pelo organismo. Dessa forma, o uso da casca de soja no nível de $20 \%$ de inclusão tornou esta silagem mais energética quando comparado aos demais.

As temperaturas das silagens e o $\mathrm{pH}$ foram influenciadas pelos níveis de inclusão $(\mathrm{P}<0,05)$. A temperatura apresentou maior elevação na silagem exclusiva de capim elefante $\left(25,2^{\circ} \mathrm{C}\right) . \mathrm{O} \mathrm{pH}$ apresentou aumento linear de $0,09 \%$ em cada $1 \%$ do aditivo adicionado a massa de forragem, com maiores teores $(4,0)$ observados nos níveis de 20 e $25 \%$, ainda assim, encontram-se na faixa considerada ótima $(3,8$ a 4,2) para fermentação adequada (ANDRADE et al., 2010).

As silagens submetidas aos tratamentos 0, 5 e 10\% de inclusão da casca de soja apresentaram pH baixo, indicando fermentação inadequada, e possível ação de 
microrganismos indesejáveis, geradores de fermentações secundárias. Mota et al. (2012) observaram maiores valores de $\mathrm{pH}$ em silagens de capim elefante sem aditivo quando comparados as silagens aditivadas de 10, 20 e 30\% de farelo de mandioca, farelo de babaçu ou faveira de bolota, discordando dos resultados encontrados nesse estudo.

Os dados referentes a população microbiológica das silagens de capim elefante aditivada com casca de soja peletizada encontram-se na Figura1. A população de bolores apresentou maior número de colônias no nível de 5\% (2,3 x 104 ufc/ml), seguido do nível de 10\% (1 x $104 \mathrm{ufc} / \mathrm{ml}$ ) em comparação aos demais tratamentos, esses resultados encontram-se acima dos citados por Bernardes et al. (2013) os quais isolaram 3,32 ufc/g de fungos em silagens exclusivas de capim elefante. Segundo Silva et al. (2010) os fungos, quando em numerosas colônias, podem alterar a concentração de carboidratos solúveis e vitaminas presentes nas silagens.

A inclusão da casca de soja na silagem de capim elefante, nos níveis avaliados, foi eficiente em diminuir a população de leveduras. Nota-se que a população de leveduras foi dominante na silagem exclusiva de capim elefante $(3,8 \times 105 \mathrm{ufc} / \mathrm{ml})$. Pereira; Rocha; Ferreira (2007) observaram população de leveduras e mofos da ordem de 103 ufc/g de silagem fresca para o capim elefante após 56 dias de fermentação. Silagem contendo leveduras acima de 105 ufc/g são vulneráveis a deterioração aeróbia, uma vez que esses microrganismos atuam principalmente na presença de oxigênio (SILVA et al., 2010).

O grupo de enterobactérias, E. coli e coliformes totais, apresentaram maior valor no tratamento com $10 \%$ de inclusão da casca de soja $(5,5 \times 105$ e 7x105 ufc/ml para E. coli e coliformes totais, respectivamente) quando comparado aos demais tratamentos. Oliveira et al.(2007) afirma que a população de enterobactérias está diretamente relacionada ao $\mathrm{pH}$, sendo que o abaixamento do $\mathrm{pH}$ pode dificultar a proliferação desses microrganismos, além disso, são formadores de ácido acético e gás carbônico, e ocasionam a perda de matéria seca e energia. Silva et al. (2011) observou que a inclusão da jaca na silagem de capim elefante diminuiu a população de enterobactérias em 0,0116 ufc/g em cada unidade de jaca adicionada, com maior população na silagem exclusiva de capim elefante (105 ufc/g de silagem). 
Figura 1. População de bolores, leveduras, E.coli e coliformes totais (em unidades formadoras de colônias - ufc/ml) em função dos níveis de adição da casca de soja nas silagens de capim elefante
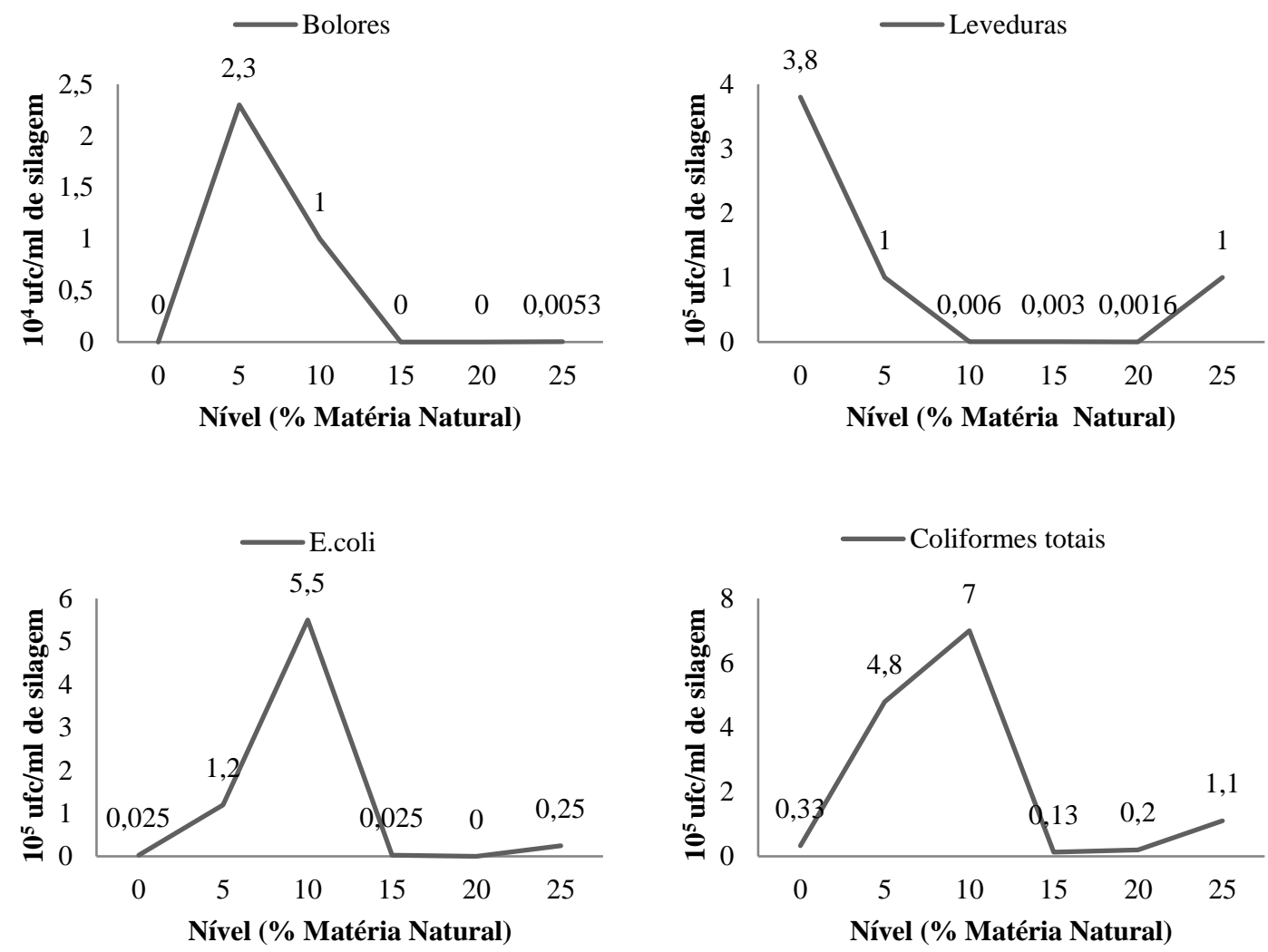

Fonte: Maia et al., (2021, p.11)

A estabilidade de uma silagem considera o tempo para esta atingir $2^{\circ} \mathrm{C}$ acima da temperatura ambiente (BALIEIRO NETO et al., 2009), desta forma, conforme o desdobramento das temperaturas durante o período de exposição aeróbia, apresentados na figura 2, observamos que as silagens com 5\% de inclusão do aditivo tiveram sua estabilidade quebrada após $24 \mathrm{~h}$ de exposição ao ar, os tratamentos com silagem exclusiva de capim elefante, 10 e $15 \%$ de inclusão da casca de soja tiveram sua temperatura aumentada em $2^{\circ} \mathrm{C}$ acima da temperatura ambiente após 36 horas enquanto os que tinham os maiores níveis inclusão (20 e 25\%) levaram 48 horas para ultrapassar $2{ }^{\circ} \mathrm{C}$ a temperatura ambiente. 
Figura 2. Variação temporal da temperatura das silagens de capim elefante com inclusão de casca de soja peletizada durante a exposição ao ar
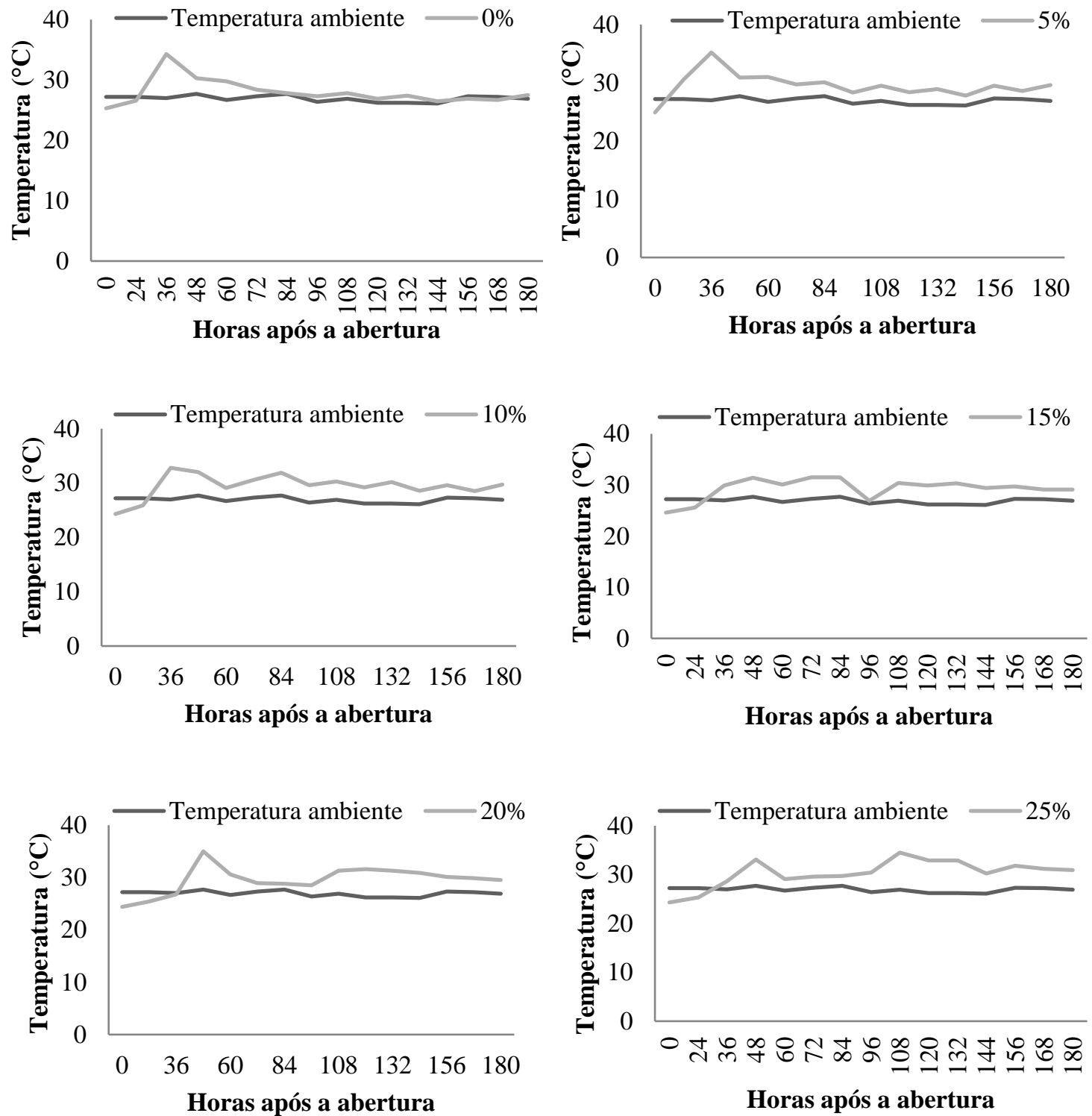

Fonte: Maia et al., (2021, p.12)

Esses resultados não corroboram com os de Bernardes et al (2008), ao avaliarem silagens de capim marandu tratadas com benzoato de sódio e inoculantes bacterianos observaram estabilidade das silagens mesmo após 6 dias de exposição aeróbia. Ávila et al. (2009) também encontraram maior estabilidade nas silagens de capim Mombaça, onde a temperatura da silagem sem inoculante teve sua estabilidade quebrada 55 horas após abertura dos silos, enquanto as silagens inoculadas permaneceram estáveis mesmo após 240 horas expostas ao ar. 
Os valores de pH, em função dos níveis de adição de casca de soja adicionados às massas de forragem, durante o período de exposição ao ambiente estão apresentados na figura 3. Observou-se que até às 24 horas após a abertura dos silos o pH manteve-se estável nos tratamentos avaliados, com rápido aumento entre as 36 e 96 horas e estabilidade em seus teores após as 96 horas de exposição ao ar. Balieiro Neto et al. (2009) observou estabilidade do $\mathrm{pH}$ até 48 horas de abertura dos silos, com acréscimo em seus valores após o avanço do tempo de exposição ao ar, em silagens de cana de açúcar tratadas com cal virgem. Por outro lado, os resultados deste estudo foram próximos aos relatados por Rabelo et al. (2012), esses autores observaram variação de 3,5 até superiores a 8,0 nos teores de $\mathrm{pH}$ em silagem de milho expostas ao ar durante 168 horas, destacando que este é um indicativo da deterioração destas silagens pela atuação de microrganismos indesejáveis.

Figura 3. Valores de $\mathrm{pH}$ das silagens de capim elefante aditivadas com níveis crescentes de casca de soja peletizada durante o período de exposição aeróbia

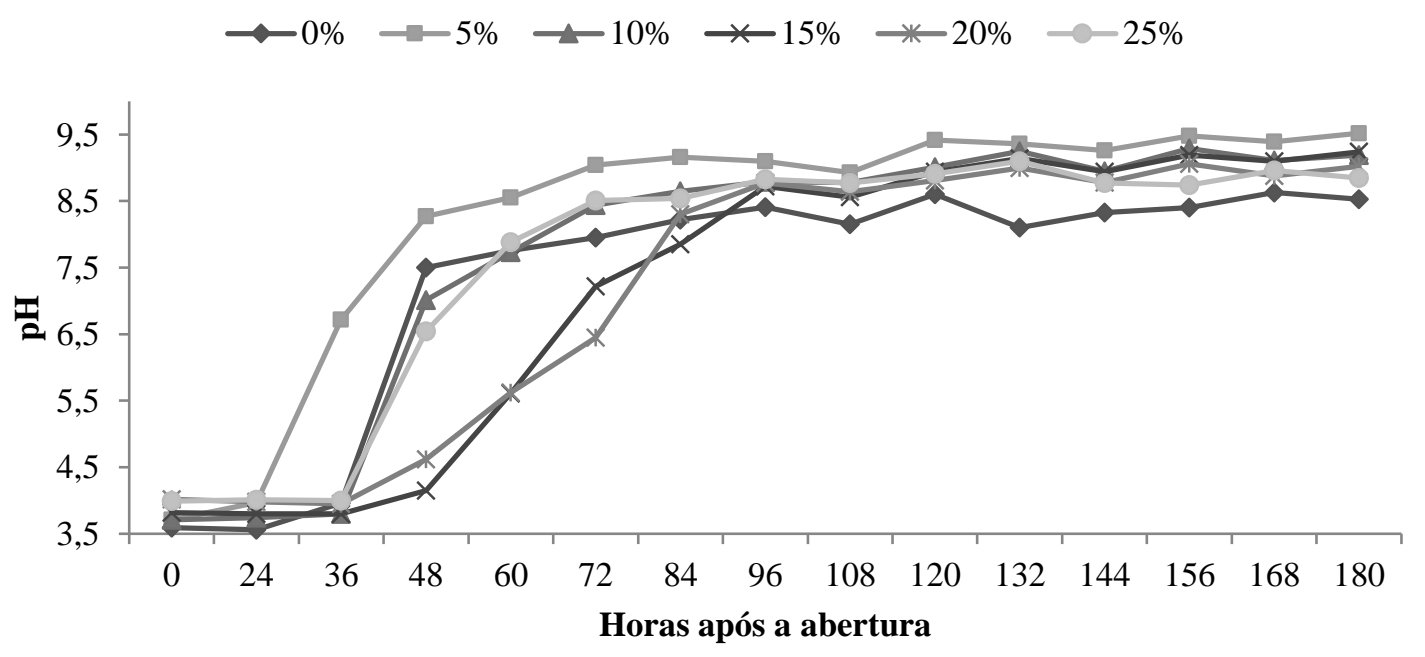

Fonte: Maia et al., (2021, p.13)

\section{CONCLUSÃO}

A casca de soja peletizada, nas condições estudadas, sequestrou a umidade das silagens de capim elefante, diminuiu a fração de fibra em detergente neutro e aumentou os teores de proteína bruta nas massas de forragem, podendo assim ser usada com 
eficiência como aditivo. Entretanto, recomenda-se sua adição em níveis acima de 15\%, por assegurar assim melhor fermentação e reduzida população microbiana.

\section{REFERÊNCIAS}

ANDRADE, A.P. et al. Aspectos qualitativos da silagem de capim-elefante com fubá de milho e casca de soja. Semina: Ciências Agrárias, v. 33, n. 3, p. 1209-1218, 2012.

ANDRADE, I.V.O. et al. Perdas, características fermentativas e valor nutritivo da silagem de capim elefante contendo subprodutos agrícolas. Revista Brasileira de Zootecnia, v. 39, n. 12, p. 2578-2588, 2010.

AOAC - ASSOCIATION OF OFFICIAL ANALYTICAL CHEMISTS. Official methods of analysis. Virginia: Arlington. 1990.

ÁVILA, C.L.S. et al. Estabilidade aeróbia de silagens de capim-mombaça tratadas com Lactobacillus buchneri. Revista Brasileira de Zootecnia, v. 38, n. 5, p. 779-787, 2009.

BALIEIRO NETO, G. et al. Perdas fermentativas e estabilidade aeróbia de silagens de cana-de-açúcar aditivadas com cal virgem. Revista Brasileira de Saúde e Produção Animal, v. 10, n.1, p. 24-33, 2009.

BERNARDES, T.F. et al. Perfil fermentativo, estabilidade aeróbia e valor nutritivo de silagens de capim-marandu ensilado com aditivos. Revista Brasileira de Zootecnia, v. 37, n.10, p. 1728-1736, 2008.

BERNARDES, T.F. et al. Uso de inoculante bacteriano e melaço na ensilagem de capim-elefante. Revista Ciências Agrárias, v.56, n. 2, p. 173-178, 2013.

BOLSEN, K.K. et al. Effect of silage additives on the microbial succession and fermentation process of alfalfa and corn silage. Journal of Dairy Science, v. 75, n. 11, p. 3066-3083, 1992.

BONFÁ, C.S. et al. Silagem de capim-elefante adicionada de casca de maracujá. Arquivo Brasileiro de Medicina Veterinária e Zootecnia, v. 67, n. 3, p. 801-808, 2015.

CASALI, A.O. et al. Estimação de teores de componentes fibrosos em alimentos para ruminantes em sacos de diferentes tecidos. Revista Brasileira de Zootecnia, v. 38, n. 1, p. 130-138, 2009.

FERREIRA, A.C.H. et al. Avaliação nutricional do subproduto da agroindústria de abacaxi como aditivo de silagem de capim-elefante. Revista Brasileira de Zootecnia, v. 38, n. 2, p. 223-229, 2009.

FERREIRA, D.F. Sisvar: A computer statistical analysis system. Ciência e Agrotecnologia, v. 35, n. 6, p. 1039-1042, 2011. 
GONZÁLEZ, G.; RODRÍGUEZ, A.A. Effect of storage method on fermentation characteristics, aerobic stability and forage intake of tropical grasses ensiled in round bales. Journal of Dairy Science, v. 86, n. 3, p. 926-933, 2013.

GUERRA, D.G.F. et al. Chemical composition of elephant grass silages supplemented with different levels of dehydrated cashew bagasse. Semina: Ciências Agrárias, v. 37 , n. 2, p. 997-1006, 2016.

LICITRA, G.; HERNANDES, T.M.; VAN SOEST, P.J. Standardization of procedures for nitrogen fractionational of ruminant feeds. Animal Feed Science and Technology, v. 57, n. 4, p. 347-358, 1996.

MAIA, I.S.A.S. et al. Valor nutritivo de silagens de capim elefante com níveis crescentes de resíduo da agroindústria da acerola. Acta Veterinária Brasílica, v. 9, n. 2, p. 190-194. 2015.

MATEUS, R.G. et al. Composição químico ᄀ-bromatológica de diferentes subprodutos da soja. Revista Brasileira de Tecnologia Aplicada nas Ciências Agrárias, v. 11, n. 1, p. 79-85, 2018.

MONTEIRO, I.J.G. et al. Silagem de capim-elefante aditivada com produtos alternativos. Acta Scientiarum. Animal Science, p. 33, n. 4, p. 347-352, 2011.

MOTA, P.E.S. et al. Características fermentativas da silagem de capim-elefante contendo diferentes aditivos. Revista Científica de Produção Animal, v. 14, n. 2, p. 133-137, 2012.

OLIVEIRA, A.C. et al. Farelo de mandioca na ensilagem de capim-elefante: fracionamento de carboidratos e proteínas e características fermentativas. Revista Brasileira de Saúde e Produção Animal, v. 13, n. 4, p. 1020-1031, 2012.

OLIVEIRA, J.S. et al. Populações microbianas e composição química de silagem de capim-mombaça (Panicum maximum) inoculado com Streptococcus bovis isolado de rúmen. Archives of Veterinary Science, v. 12, n. 2, p. 35-40, 2007.

OLIVEIRA, T.S. et al. Composição químico-bromatológica do capim-elefante submetido à adubação química e orgânica. Revista Brasileira de Saúde e Produção Animal, v. 12, n. 1, p. 32-42, 2011.

PEREIRA, O.G.; ROCHA, K.D.; FERREIRA, C.L.L.F. Composição química, caracterização e quantificação da população de microrganismos em capim-elefante cv. Cameroon (Pennisetum purpureum, Schum.) e suas silagens. Revista Brasileira de Zootecnia, v. 36, n. 6, p. 1742-1750, 2007.

RABELO, C.H.S. et al. Perdas fermentativas e estabilidade aeróbia de silagens de milho inoculadas com bactérias ácido-láticas em diferentes estádios de maturidade. Revista Brasileira de Saúde e Produção Animal, v. 13, n. 3, p. 656-668, 2012. 
RÊGO, M.M.T. et al. Chemical and bromatological characteristics of elephant grass silages containing a mango by-product. Revista Brasileira de Zootecnia, v. 39, n. 1, p. 81-87, 2010.

RIBEIRO, J.L. et al. Efeitos de absorventes de umidade e de aditivos químicos e microbianos sobre o valor nutritivo, o perfil fermentativo e as perdas em silagens de capim-marandu. Revista Brasileira de Zootecnia, v. 38, n. 2, p. 230-239, 2009.

RODRIGUES RC. Métodos de análises bromatológicas de alimentos: métodos físicos, químicos e bromatológicos. Pelotas: Embrapa Clima Temperado, 2010.

SILVA, D. J.; QUEIROZ, A. C. Análise de alimentos: métodos químicos e biológicos. 3. ed. Viçosa: UFV, 2002.

SILVA, J.M. et al. Influência de inoculante bacteriano-enzimático sobre a microbiota e qualidade nutricional de silagens de grãos úmidos de milho. Revista Ciência Animal Brasileira, v. 11, n. 1, p. 62-72, 2010.

SILVA, N. et al. Manual de métodos de análise microbiológica de alimentos. 3.ed. Santa Maria, RS: Editora Universidade Federal de Santa Maria, 2007.

SILVA, T.C. et al. Populações microbianas, perfil fermentativo e composição de silagens de capim-elefante com jaca. Revista Archivos de Zootecnia, v. 60, n. 230, p. 247-255, 2011.

SNIFFEN, C.J. et al. A net carbohydrate and protein system for evaluating cattle diets: II. Carbohydrate and protein availability. Journal of Animal Science, v. 70, p. 35623577, 1992.

STELLA, L.A. et al. Composição química das silagens de milho e sorgo com inclusão de planta inteira de soja. Boletim de Indústria Animal, v. 73, n. 1, p. 73-79, 2016.

VAN SOEST, P.J.; ROBERTSON, J.B.; LEWIS, B.A. Methods for dietary fiber, neutral detergent fiber, and nonstarch polysaccharides in relation to animal nutrition. Journal of Dairy Science, v. 74, n. 10, p. 3583-3597, 1991.

WEISS, W.P. Energy prediction equations for ruminant feeds. In: CORNELL NUTRITION CONFERENCE FOR FEED MANUFACTURERS, 61., 1999, Ithaca. Proceedings[...] Ithaca: Cornell University, 1999. p.176-18 